\title{
Erratum in Wilderness Environ Med. 2016
}

Wilderness Environ Med. 2016 27(4):504-518. http://dx.doi.org/10.1016/j.wem.2016.08.003.

Clinical and Epidemiological Aspects of Scorpionism in the World: A Systematic Review

Santos MS, Silva CG, Neto BS, Grangeiro Júnior CR, Lopes VH, Teixeira Júnior AG, Bezerra DA, Luna JV, Cordeiro JB, Júnior JG, Lima MA.

Figure 2

The genus "Mesobuthus" was removed from the label on Brazil map.

\section{Table 3}

The species "Mesobuthus gibbosus" was removed from the row 5 of the second column (Kotviski and Barbola, 2013)

The sum of cases from the study of Chowell et al (2005) was adjusted to 13,936 (instead of 12,176) (row 14, column 3)

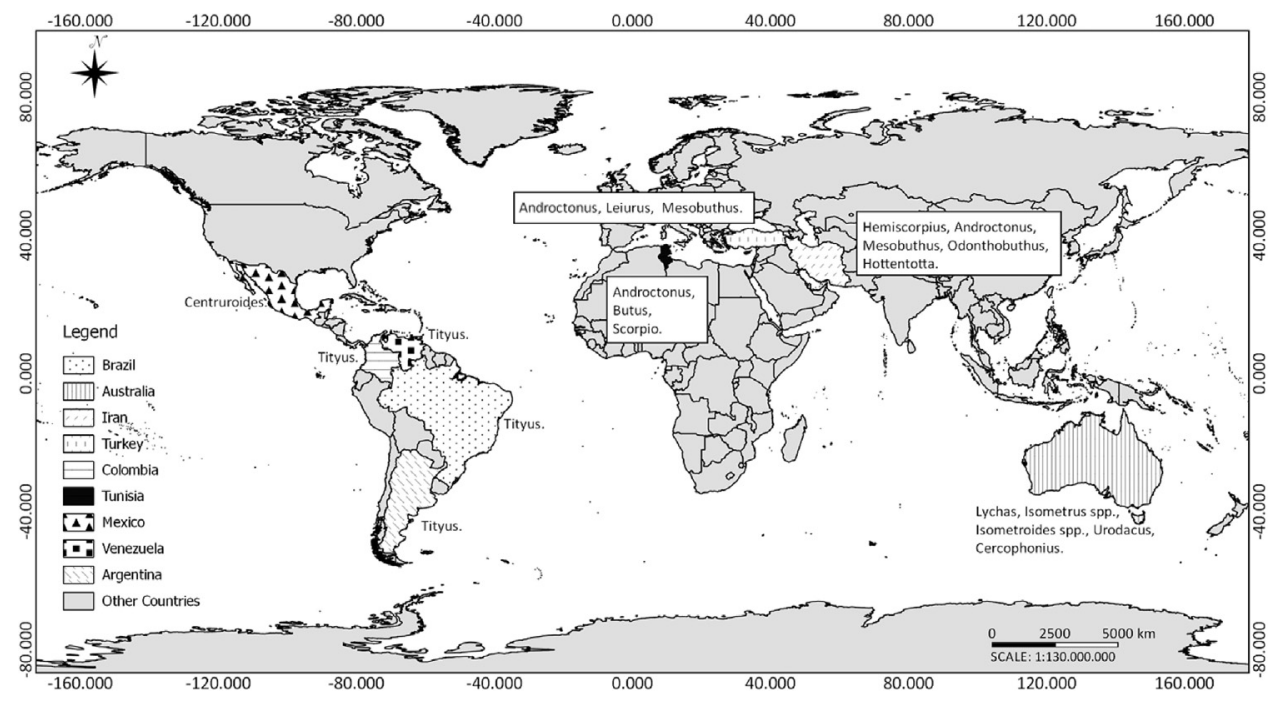

Figure 2. 
Table 3. Epidemiological aspects of scorpionism in the most affected world areas

\begin{tabular}{|c|c|c|c|c|c|c|c|}
\hline Country & Taxonomy & Number of cases & Sex & Age & Time of year & Sting location & Author (Year) \\
\hline Argentina & Tityus trivittatus & 511 & $\begin{array}{l}52 \% \text { Male; } 48 \% \\
\text { Female. }\end{array}$ & $\begin{array}{l}\text { The proportion of } \\
\text { accidents reported } \\
\text { involving children } \\
\text { up to } 10 \text { years old } \\
\text { was significantly } \\
\text { higher than those } \\
\text { reported involving } \\
\text { people between } 11 \\
\text { and } 50 \text { years old }\end{array}$ & $\begin{array}{l}\text { Most accidents took } \\
\text { place during the } \\
\text { period November- } \\
\text { April }(76 \%) \text {. Also, } \\
84 \% \text { of the accidents } \\
\text { took place in the } \\
\text { warmest months } \\
\text { (October-April). }\end{array}$ & $\begin{array}{l}\text { Feet }(40 \%) \\
\text { Hands }(32 \%) \\
\text { Arms }(11 \%) \\
\text { Legs }(10 \%) \\
\text { Chest }(5 \%) \\
\text { Head }(2 \%) .\end{array}$ & de Roodt et al $(2003)^{16}$ \\
\hline Australia & $\begin{array}{l}\text { Lychas marmoreusa } \\
\text { Lychas variatus, Lychas } \\
\text { spp., Isometrus spp., } \\
\text { Isometroides spp. } U . \\
\text { armatus, } U . \\
\text { novaehollandiae, } U . \\
\text { planimanus, } \\
\text { Cercophonius squam }\end{array}$ & 95 & $\begin{array}{l}33 \text { males; } 62 \\
\text { females. }\end{array}$ & $\begin{array}{l}\text { Age ranged from } 1 \\
\text { to } 85 \text { years with a } \\
\text { median age of } 33 \\
\text { years. There were } 23 \\
\text { pediatric cases (ages } \\
<15 \text { years). }\end{array}$ & $\begin{array}{l}\text { The majority of } \\
\text { stings occurred in } \\
\text { the warmer months } \\
\text { (November, } \\
\text { December, January, } \\
\text { February). }\end{array}$ & $\begin{array}{l}\text { Stings occurred to } \\
\text { all parts of the body, } \\
\text { with } 60 \% \text { distal } \\
\text { (hand or foot), } 26 \% \\
\text { on the proximal } \\
\text { limb, } 8 \% \text { on the } \\
\text { trunk, } 4 \% \text { on the } \\
\text { head/neck and } 1 \% \\
\text { on multiple regions. }\end{array}$ & Isbister et al $(2003 b)^{19}$ \\
\hline \multirow[t]{4}{*}{ Brazil } & $\begin{array}{l}\text { Tityus stigmurus } \\
\text { (Buthidae) }\end{array}$ & 5561 & $\begin{array}{l}856 \text { male }(53.0 \%) \\
762 \text { female }(47.0 \%)\end{array}$ & $\begin{array}{l}<5=661(40.9 \%) \\
06 \text { to } 09=503 \\
(31.1 \%) \\
10 \text { to } 12=428 \\
(26.5 \%) \\
\text { Unknown }=26 \\
(1.6 \%)\end{array}$ & $\begin{array}{l}\text { The accidents } \\
\text { occurred year-round, } \\
\text { although an average } \\
\text { increase of } 4 \% \text { was } \\
\text { registered during the } \\
\text { rainy season from } \\
\text { June through August }\end{array}$ & $\begin{array}{l}\text { Hands/Arms, } 842 \\
(52.0 \%) ; \text { legs, } 554 \\
(34.3 \%) ; \text { thorax, } 78 \\
(4.8 \%) ; \text { head, } 15 \\
(0.9 \%) ; \text { unknown, } \\
129(8.0 \%)\end{array}$ & $\begin{array}{l}\text { Albuquerque et al } \\
(2013)^{9}\end{array}$ \\
\hline & Tityus serrulatus & 353 & - & - & - & - & $\begin{array}{l}\text { Kotviski and Barbola } \\
(2013)^{45}\end{array}$ \\
\hline & - & 82 & $\begin{array}{l}\text { The prevalence of } \\
\text { victims of scorpion } \\
\text { envenomation was } \\
\text { slightly higher }(6 \%) \\
\text { for men than for } \\
\text { women }(5.2 \%) \text {. }\end{array}$ & $\begin{array}{l}\text { The current age of } \\
\text { the interviewees } \\
\text { ranged from } 0 \text { to } 93 \text {, } \\
\text { with most of the } \\
\text { population between } \\
15 \text { and } 52(62.1 \%) \\
\text { years. }\end{array}$ & $\begin{array}{l}\text { Higher incidence } \\
\text { was recorded from } \\
\text { January to July }\end{array}$ & - & $\begin{array}{l}\text { de Amorim et al } \\
(2003)^{46}\end{array}$ \\
\hline & Tityus cambridgei & 72 & $\begin{array}{l}\text { The majority of } \\
\text { victims were } \\
\text { male }(83.3 \%)\end{array}$ & $\begin{array}{l}\text { The age was } \\
33.6 \pm 18.3 \\
\text { (mean } \pm \mathrm{SD} \text { ) } \\
\text { years }\end{array}$ & $\begin{array}{l}\text { The majority } \\
(81.9 \%) \text { of the } \\
\text { accidents occurred } \\
\text { in the day, with }\end{array}$ & $\begin{array}{l}\text { The upper limb was } \\
\text { affected in } 51.5 \% \text { of } \\
\text { cases and } 41.1 \% \text { in } \\
\text { the hand; the leg }\end{array}$ & Pardal et al $(2003)^{28}$ \\
\hline
\end{tabular}


Table 3 (continued)

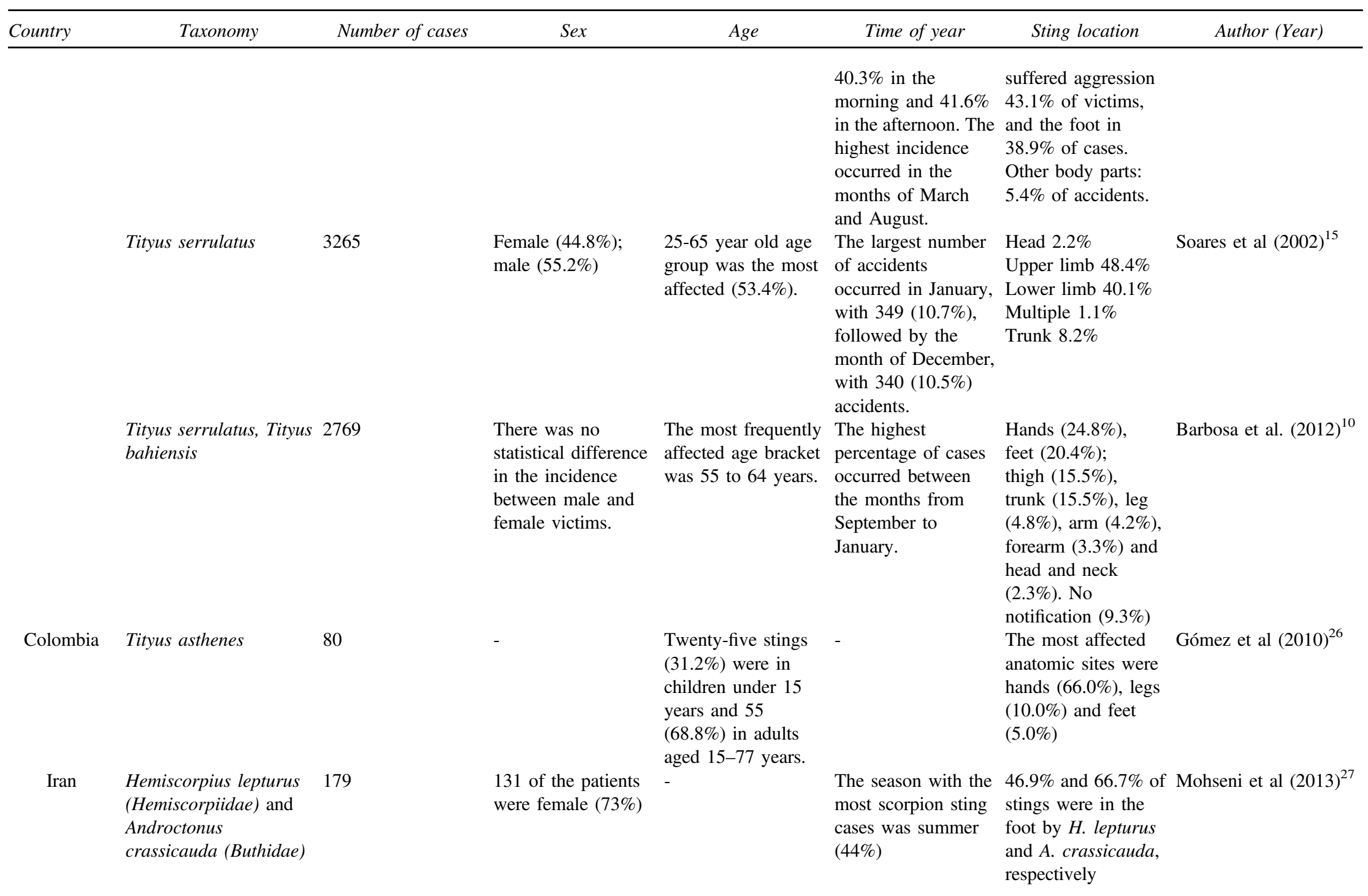


Mesobuthus eupeus,

12,150

Hottentotta saulcyi,

Odonthobuthus doriae

Hemiscorpius lepturus,

Androctonus

crassicauda and

Hottentotta schach

Mexico Centruroides nigrenses, 1174

Centruroides limpidus

limpidus

Centruroides infamatus 13,936

infamatus, Centruroides

limpidus tecomanus

Tunisia Androctonus australus, 685

Butus occitanus

Androctonus australus, 951

Butus occitanus and

Scorpio maurus.

Turkey

Androcronus

crassicauda, Leiurus

quinquestratus,

Mesobuthus gibbosus

and $M$. eupeus
$52.3 \%$ Female;

$47.7 \%$ Male.

(2)

$39.3 \%$ of stings

incidence rate of the accidents took place were on the hand

scorpion stings fell in the warmest

and $37.3 \%$ on the

Shahbazzadeh et al

$(2009)^{29}$

in the group aged 6- months of the year feet.

45 years.

(April-October), but

the highest

frequency is in June

$(16.0 \%)$.

Predominant age
range was $18-50$

years $(80 \%)$

$\left(\frac{10}{20}\right.$

$-$

Lagunas-Flores and

Lagunas-Jaimes

$(2009)^{47}$

Chowell et al (2005) ${ }^{18}$

years, ranging from more frequent in the $(80.5 \%)$ child

$0.5-15$ years. The summer; $81.7 \%$ of The frequency of

majority of patients patients were

were less than $5 \quad$ admitted between (60.4\%) and hands

years of age

June and September. (12.3\%) was greater

$(56.7 \%)$.

than those on the chest $(5.5 \%)$ and head $(2.3 \%)$.

The age was
$14.7 \pm 17.4$ (mean

Scorpion

$\pm \mathrm{SD})$ years,

more frequent

ranging from 0.5-90 during summer.

years.

$82.3 \%$ of our

patients were

admitted between

June and September.

$50.2 \%$ female

$45.5 \%$ male

Male: 0-19 age

Most of the cases,

groups. Female: $511(55.0 \%)$, were

Cesaretli and Ozkan

patients aged 20 and notified during the

over. Also, 20-29 summer period

age group presented

more scorpion stings

$(24.6 \%)$ than the

other groups 


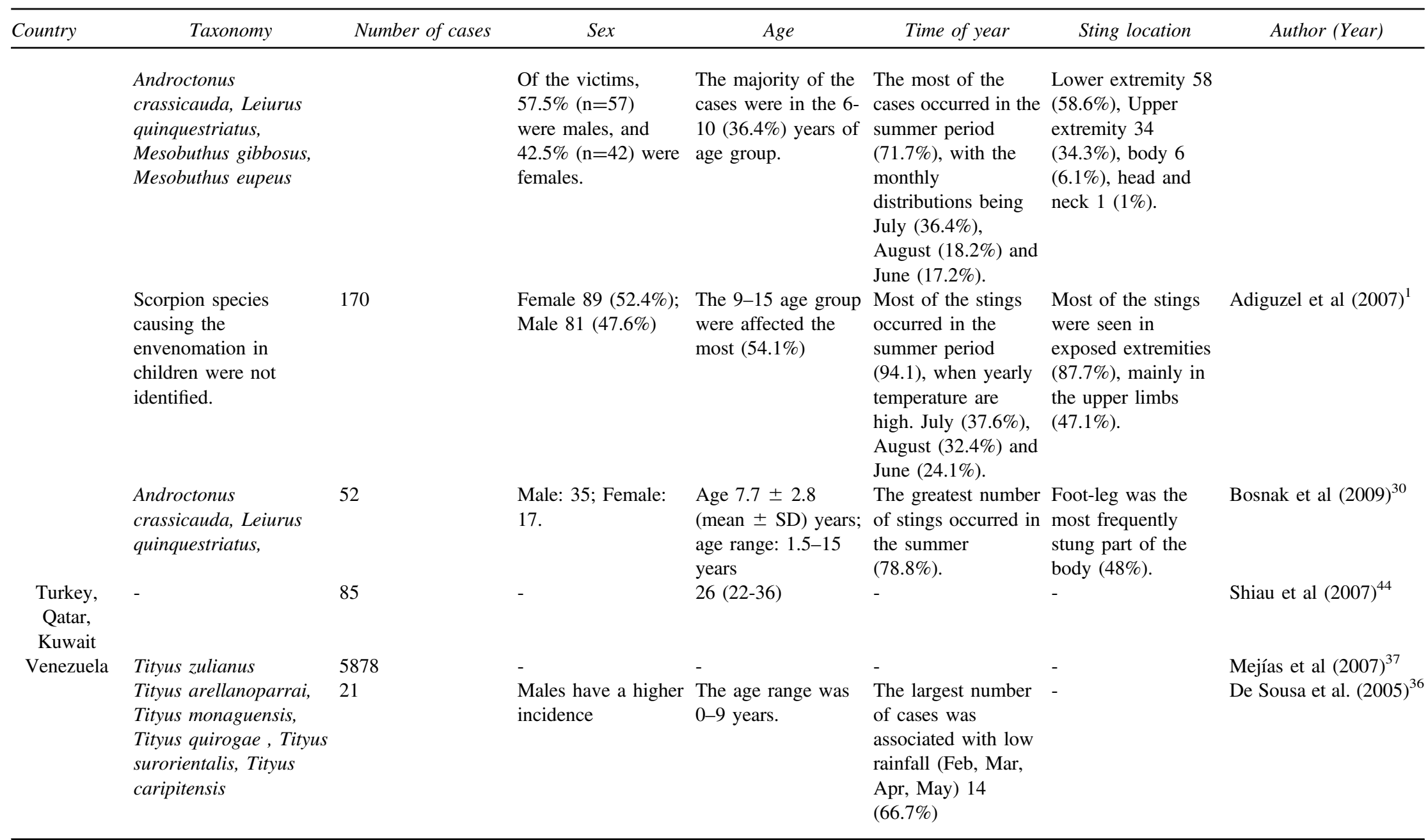

